\title{
To the problem of development of low-rise housing in Russia
}

\author{
Valentina Tusnina * and Ekaterina Yakovleva \\ Moscow State University of Civil Engineering, Yaroslavskoe shosse, 26, Moscow, 129337, Russia
}

\begin{abstract}
The issue of providing the population with comfortable and affordable housing has always been rather acute in our country. The solution to this problem, taking into account the trends in the creation and transformation of the urban environment into the most reliable, comfortable and affordable, may be the mass construction of low-rise housing. Of primary importance in solving the problem of mass construction of low-rise housing is the maximum industrialization of construction and installation work, which should be provided at the design stage in order to reduce labor costs at the construction site, where only assembly and installation work from structures of full factory readiness should be performed. In this aspect, the unification in the design and production of building steel structures will allow creating a system of typical design of civil buildings, including low-rise residential buildings, on the basis of steel frames for mass construction and solving the problem of affordable and comfortable housing in Russia.
\end{abstract}

The urban environment is an artificial space that organizes almost all human life processes, it is in it that most of the interactions of people with each other occur, so it is important to pay due attention to its formation.

Modern cities, and especially capitals, are developing at an incredible speed, and, since 2008, more than half of the world's population lives in them [1]. This trend can not affect the quality of life in the city. For many years we have been witnessing an increase in housing construction, since, first of all, the desire of people to the city is due to the desire to improve their financial situation, as well as to improve the level and quality of life. Most of them are considering in the future the possibility of acquiring modern and comfortable housing in the city.

Back in 2014, the volume of housing construction in Russia exceeded the record figures of the Soviet period and, despite the crisis, we still observe its growth [2]. The boundaries of cities are gradually expanding both through the annexation of new territories and through the airspace (an increase in the number of floors of buildings). As of April 2018, the average number of floors of residential real estate is 16.3 floors [3], while in the Soviet period it did not exceed 10 floors.

The rise in the number of floors in residential buildings is due to the fact that the price of the land plot set aside for construction is quite high, and developers, in pursuit of

\footnotetext{
* Corresponding author: valmalaz@ mail.ru
} 
reducing their expenses, aim to get maximum profit from one object. This is also due to the fact that the demand for housing significantly exceeds the capacity of urban areas for comfortable resettlement of all comers. Therefore, in the total volume of housing construction in cities, the construction of multi-storey residential buildings prevails.

The construction of the city has a shortage of social facilities. Some government agencies are trying to solve this problem by imposing on the developer responsibility for the construction of a certain number of social infrastructure facilities. However, this approach does not solve all the problems that the construction of apartment buildings brings. Some of them are most acutely felt over time. In this case, we are talking about the development of the transport system of the built-up area, the lack of parking spaces and the inability to provide the necessary throughput capacity of the city's transport arteries. These and other problems associated with the construction of such buildings in the conditions of dense urban development, significantly complicate the life of a citizen. In recent years, the Ministry of Construction and Housing and Communal Services of the Russian Federation has designated the formation of a comfortable urban environment as one of the priority projects to improve the quality of life of a city dweller. The purpose of this program is to create conditions for improving the quality and comfort of the urban environment throughout the Russian Federation through a series of priority measures to improve the urban environment (courtyards, city parks, public recreation, etc.), reconstruction and demolition of buildings recognized emergency [4].

Improvement and creation of a comfortable environment as a whole is a set of measures for the development of a space that is most adapted to the needs of its inhabitants. An important role in the sustainable and balanced development of any settlement is assigned to urban planning. It allows you to organize the territory in such a way as to create places for work, housing, as well as areas for recreation and culture. At the same time, it should be understood that the urban environment is the space in which human socialization takes place. It has a direct impact not only on the physiological, but also the emotional state of people, shaping the psychological needs of a person [5].

After analyzing the planning structures of various cities, historical aspects and geological features of the territories that in one way or another influenced the formation of the outlines of the city, we can trace the pattern - the more attention is paid to the human scale, the higher the quality of urban life. Vivid examples of this are the cities of Italy, France, Germany, Finland, where low-rise buildings are preferred. Demand and supply for housing of this type in these countries is constantly growing, and the energy efficiency of construction is many times higher than the achieved level in our country. An example of this is the project of the experimental residential district Viikki in Finland implemented in 2004 [6]. On average, about $80 \%$ of the housing stock in European countries is low-rise, unlike in the Russian Federation, where $80 \%$ of the population lives in apartment buildings. Indicative in this respect is the experience of the United States, where in 2003 more than 250 million square meters were erected. meters of housing, of which 230 million are individual cottage-type houses. Such proportions of construction are not even in the Moscow region, where the number of cottages is the largest in Russia [7].

Speaking about the design of the city, it is necessary to focus on the human perception of the environment, as well as on its mobility, since it is the biological basis of any of its activities. In the course of evolution, the sensory and musculoskeletal system of a person was formed horizontally oriented. They are best perceived objects with small size, such as building small and medium-sized floors, where more attention is attracted to the details of the lower floors of buildings. In general, the higher the object of interest is, the more difficult it is for a person to see or consider something, for this it is necessary to move some distance. The connection between the plane of the street and high buildings in the 
conditions of dense urban development is lost after the fifth floor, since "space is necessary for human interaction with the city" [8].

According to official statistics, 66 percent of our country's population would like to live in an individual home [9]. But, despite the fact that the state policy today is aimed at creating a comfortable urban environment, the legislation does not provide incentives for low-rise construction, normative acts of urban planning zoning and territorial planning are not sufficiently developed in most regions of the country. This leads to the fact that developers give their preference to the construction of multi-storey buildings. However, according to the data of the national project "Affordable and Comfortable Housing for the Citizens of Russia", in a large number of cities there was a tendency of growth of low-rise construction [10]. Such dynamics may be due to a number of significant advantages of the construction of low-rise housing, which include the following:

1. The cost of building low-rise buildings, including private ones, is often much lower than buying an apartment. For example, the average actual cost of building one square meter of the total area in the Moscow region in cities and urban-type settlements is 44,964 rubles [11], while the cost of one square meter of the total area, for example, a brick house connected to utility networks is about 35,000 rubles.

2. The cost of maintaining and maintaining low-rise buildings is significantly lower compared to multi-storey buildings [12].

3. From the point of view of energy efficiency and environmental friendliness, low-rise houses far exceed multi-storey buildings. An example is the experience of foreign engineers who use wind generators and solar panels to illuminate villages, and heat their buildings when processing garbage under high temperatures [13].

4. From the point of view of a person's emotional perception of the surrounding buildings, low-rise buildings are more comfortable than high-rise ones [14].

5. The construction of low-rise housing indirectly affects the positive change in the demographic situation in our country. A family living in an individual house with a plot of land will be more willing to give birth to a second or third child than a family living in an apartment building. In this aspect, the construction of low-rise buildings will stimulate the development of projects in the field of health and education.

The task of modern specialists in the field of construction is the formation of a new or transformation of an existing urban environment into a functionally comfortable, reliable, safe and aesthetically attractive building, both externally and internally. All this can be achieved through the organization of space, the development of architectural forms, spaceplanning, design solutions and engineering and technical support of buildings and structures for various purposes, including low-rise housing.

Detailed development of projects to create standard space-planning and design solutions (modules) of low-rise buildings will significantly reduce the cost of housing. Modern technologies are able to provide a lower cost of building envelope and at the same time maintain the required level of thermal efficiency that meets modern requirements. As noted earlier, in low-rise buildings, the environmental component is more favorable, which creates comfortable conditions for people to live. The percentage of landscaping per each resident is much higher, and the number of road transport per unit area is less.

Modern construction and production technologies over the past decades have made great strides. The issue of providing the population with comfortable and affordable housing has always been quite acute in our country, and the only slowing factors were the speed of construction and durability of the buildings themselves. The solution to this problem, taking into account the trends in the creation and transformation of the urban environment into the most reliable, comfortable and affordable, may be the massive construction of frame residential buildings up to 5 floors high with the use of steel structures. 
Recently in our country frame housing is gaining popularity. In residential multi-storey buildings of traditional type, frames are used mainly for the purpose of creating a free layout on the first floors, where shops, service facilities, etc. are located. At the same time, the use of a frame constructive system for low-rise, including individual, residential buildings also takes place in the construction of housing. With the arrival of light steel structures (LSTS) on the domestic construction market, they began to massively build residential buildings in the manor houses in Russia. However, the experience of building such buildings has shown the impossibility of their effective operation in certain climatic regions of our country [15].

The positive dynamics of the construction of frame buildings made of steel structures is due to a number of advantages in relation to the construction of buildings with a wall structural system. The construction of low-rise housing from steel structures, in addition to the variability of space-planning and architectural solutions characteristic of frame systems, is characterized by the following advantages:

- less material consumption in comparison with reinforced concrete frames;

- the presence of a wide base of metal and cold-formed profiles in the domestic industry;

- quick installation of the frame of the elements of maximum factory readiness;

- low labor intensity due to the limited number of standard sizes of structural elements used for typical sections (modules);

- low cost of the frame (including installation) of rolling I-beams and welded profiles compared to the cost of the reinforced concrete frame or of LSTC (light steel thin-walled structures) [16];

- the presence of the domestic regulatory framework for the design and construction of steel frames made of rolled and welded profiles $[16,17]$.

Calculation and design of steel frames for low-rise construction showed that the frame system with bearing structural elements of rolled and welded profiles can be effectively used for the construction of low-rise housing.

Today, specialists of Moscow State Construction University are working on the problem of introducing mass steel frame buildings into the practice of mass building, developing space-planning and design solutions for such buildings [16-21].

Based on the normative documents on the design of housing [22, 23] and the results of calculations of steel frames of low-rise buildings [16, 21], space-planning solutions were developed for individual and multi-family residential buildings of average height. The development of the planning elements of the apartments (standard modules) was carried out taking into account certain standard sizes of the steel frame cells [16]: 6x6, 6x3 and 3x3 m, which made it possible to compactly organize "standard housing". Due to various combinations of standard modules, it is possible to create various types of residential buildings, both in terms of architectural and compositional solutions, and in orientation of residential premises along the cardinal points.

The development of planning solutions for various types of residential buildings was based on a typical structural cell with dimensions in the plan of $6 \times 6 \mathrm{~m}$, which allowed to place inside it a one-room apartment that meets the normals of the planning elements of residential buildings (Fig. 1).

Additional planning modules: $6 \times 3$ and $3 \times 3 \mathrm{~m}$ were used to accommodate communication and utility rooms, as well as to increase the living space of the apartments (Fig. 2). Module $3 \times 3 \mathrm{~m}$ was used as a connecting element of the common areas.

Residential development is projected and carried out in the most diverse climatic and urban conditions, which directly affects the spatial organization of the territory and spaceplanning solutions of buildings. On the territory of Russia, in the structure of cities, urbantype settlements, villages, there are various morphotypes of it, often combined with each other (perimeter, lowercase, group, net, carpet building, etc.). For such types of buildings, 
the pivoting and corner planning elements of residential buildings of the gallery (Fig. 2) and corridor (Fig. 3) types using the 6x6 and 6x3 m modules have been developed.

Recently, in the construction of cottage settlements used blocked residential buildings, widespread abroad. A characteristic feature of such housing is the presence of a private plot. The developed modules can be successfully applied in the design of blocked as well as manor-type residential buildings (Fig. 4).

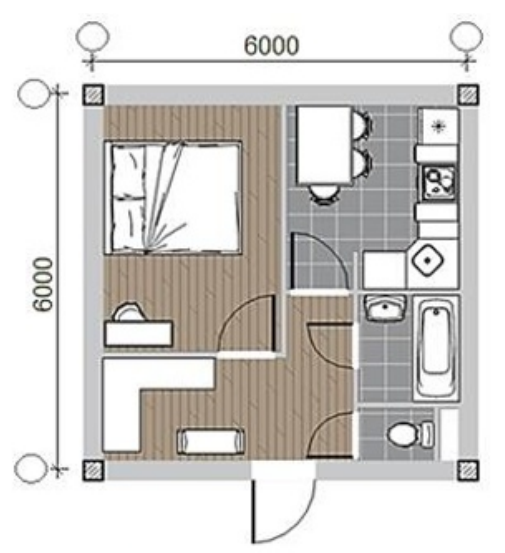

ว

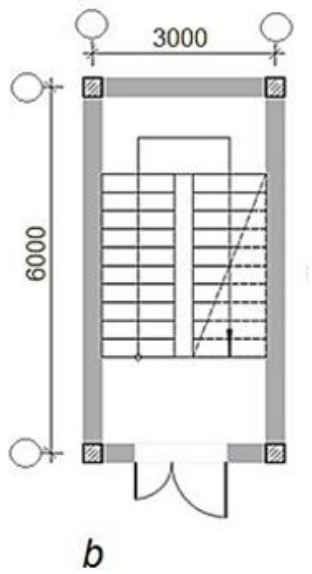

$b$

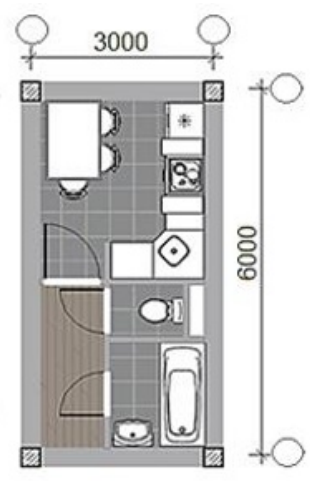

Fig. 1. Typical planning modules: a - main $6 \times 6 \mathrm{~m}$; b - additional $6 \times 3 \mathrm{~m}$
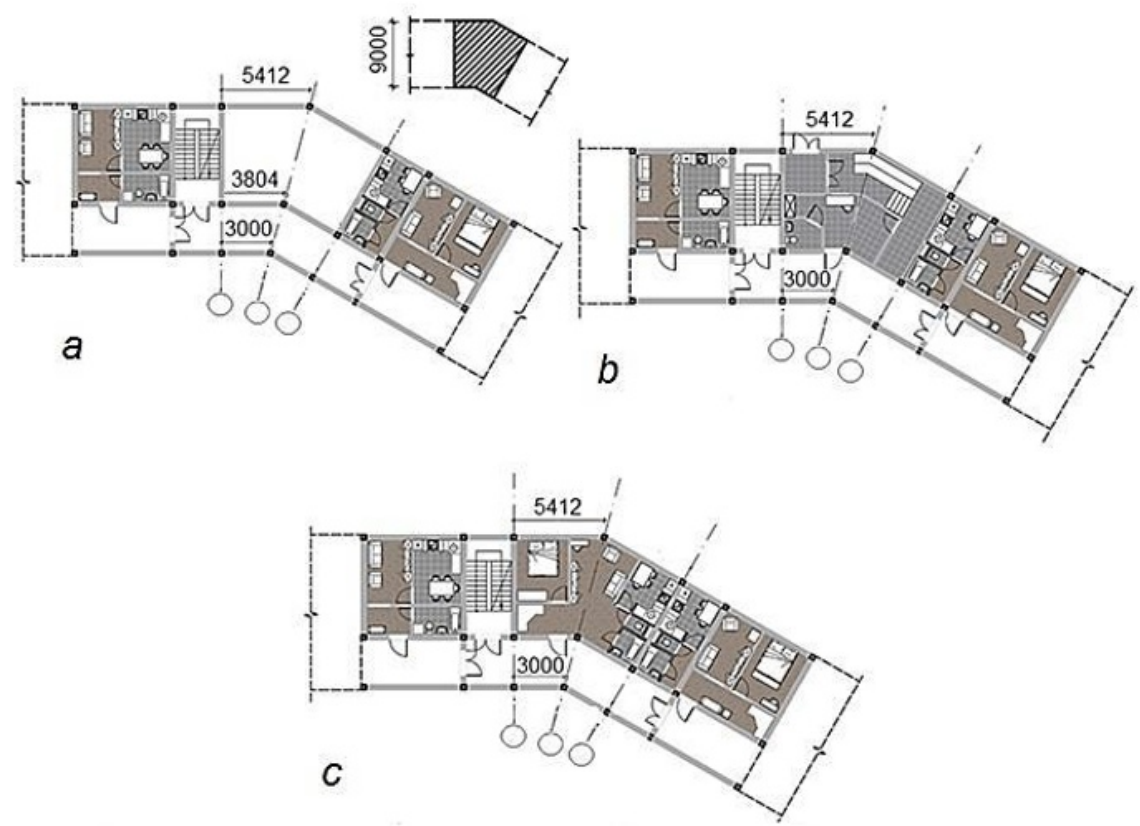

Fig. 2. Angle module for gallery-type buildings: a - general shape and dimensions; $\mathrm{b}$ - plan of the ground floor; $\mathrm{c}$ - plan of the typical floor 


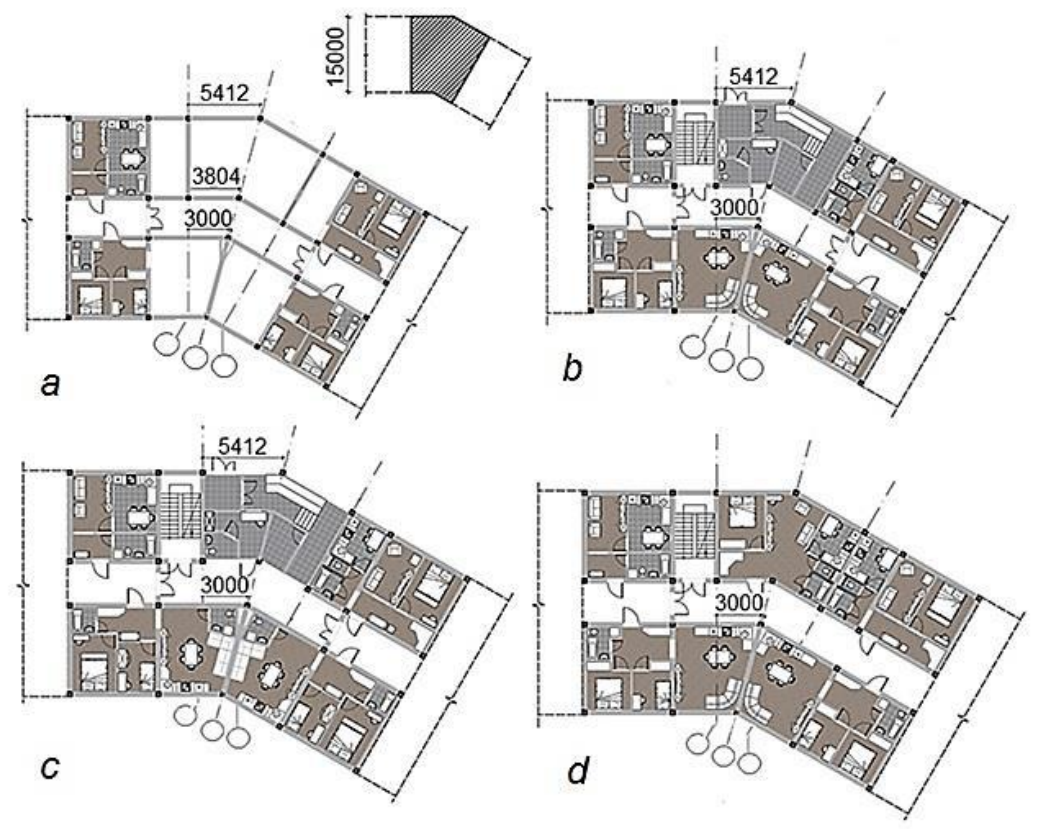

Fig. 3. Corner module for corridor-type buildings: a - general shape and size; b, c - variants of the plan of the ground floor; $\mathrm{d}$ - plan of the typical floor

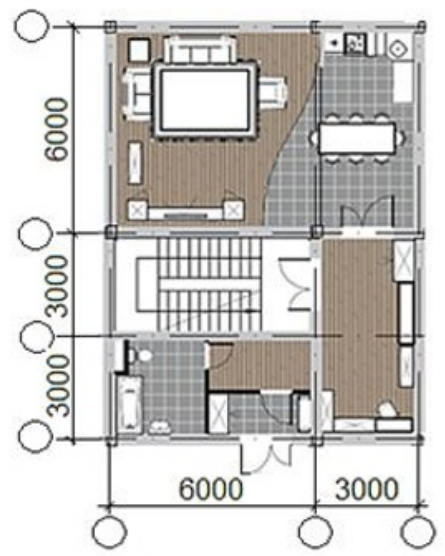

a

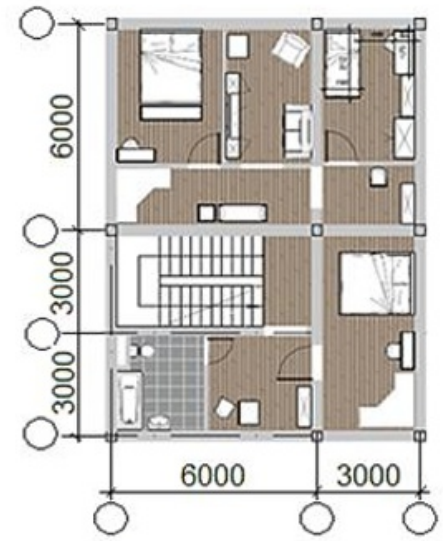

$b$

Fig. 4. The building of the manor type: a - plan of the 1st floor; $b$ - plan of the 2nd floor

The developed variants of planning decisions for residential buildings of various types based on steel frames are presented in Fig. 5. 

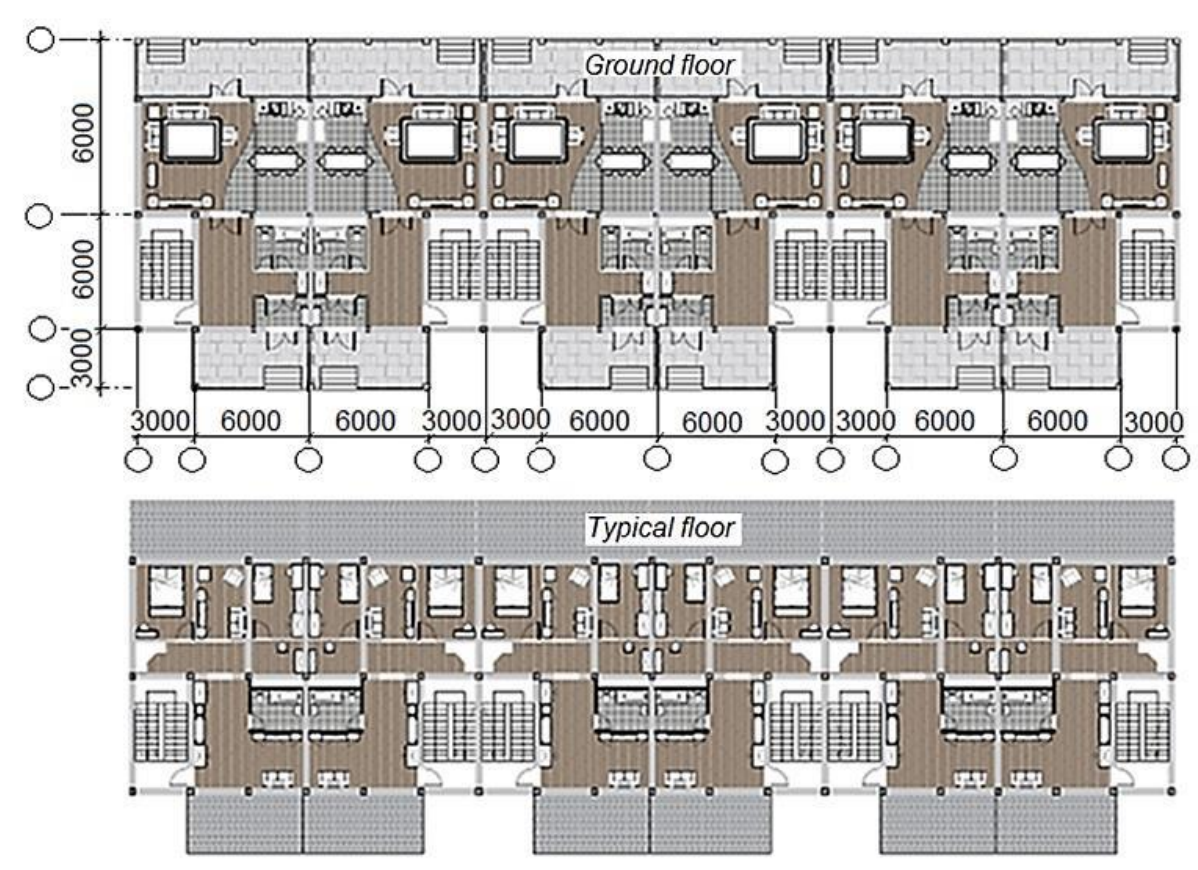

a
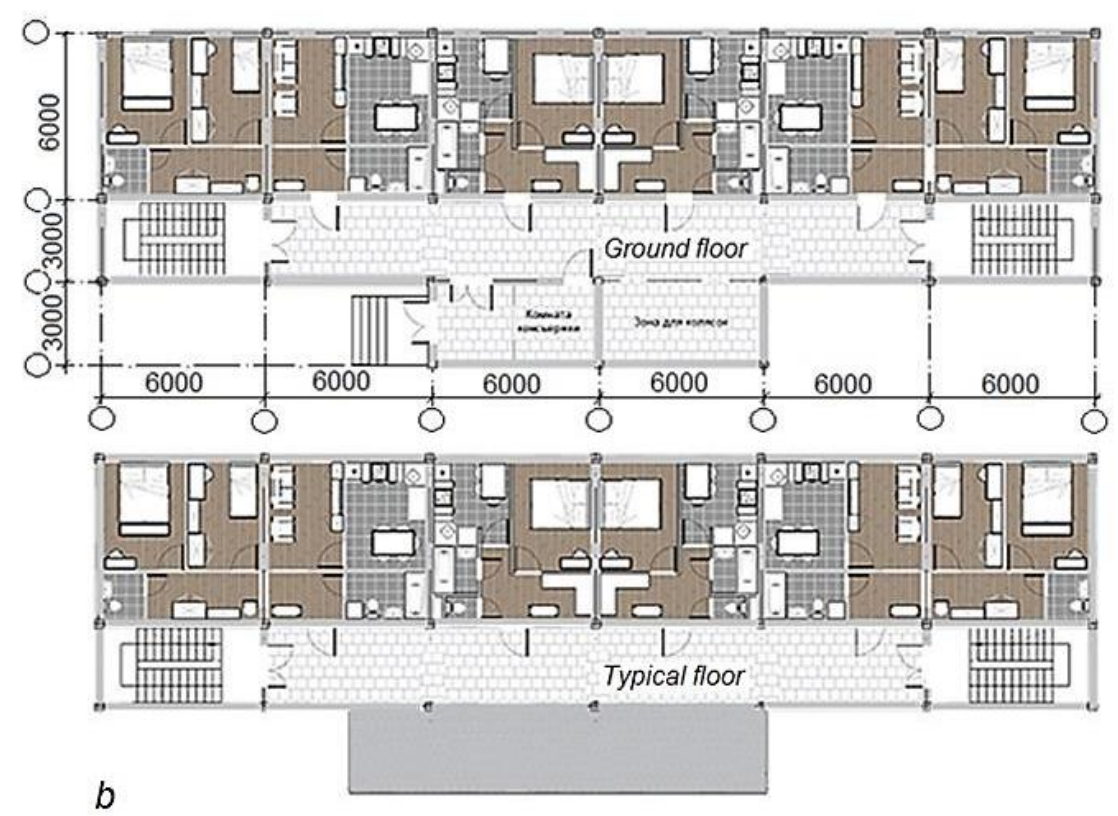

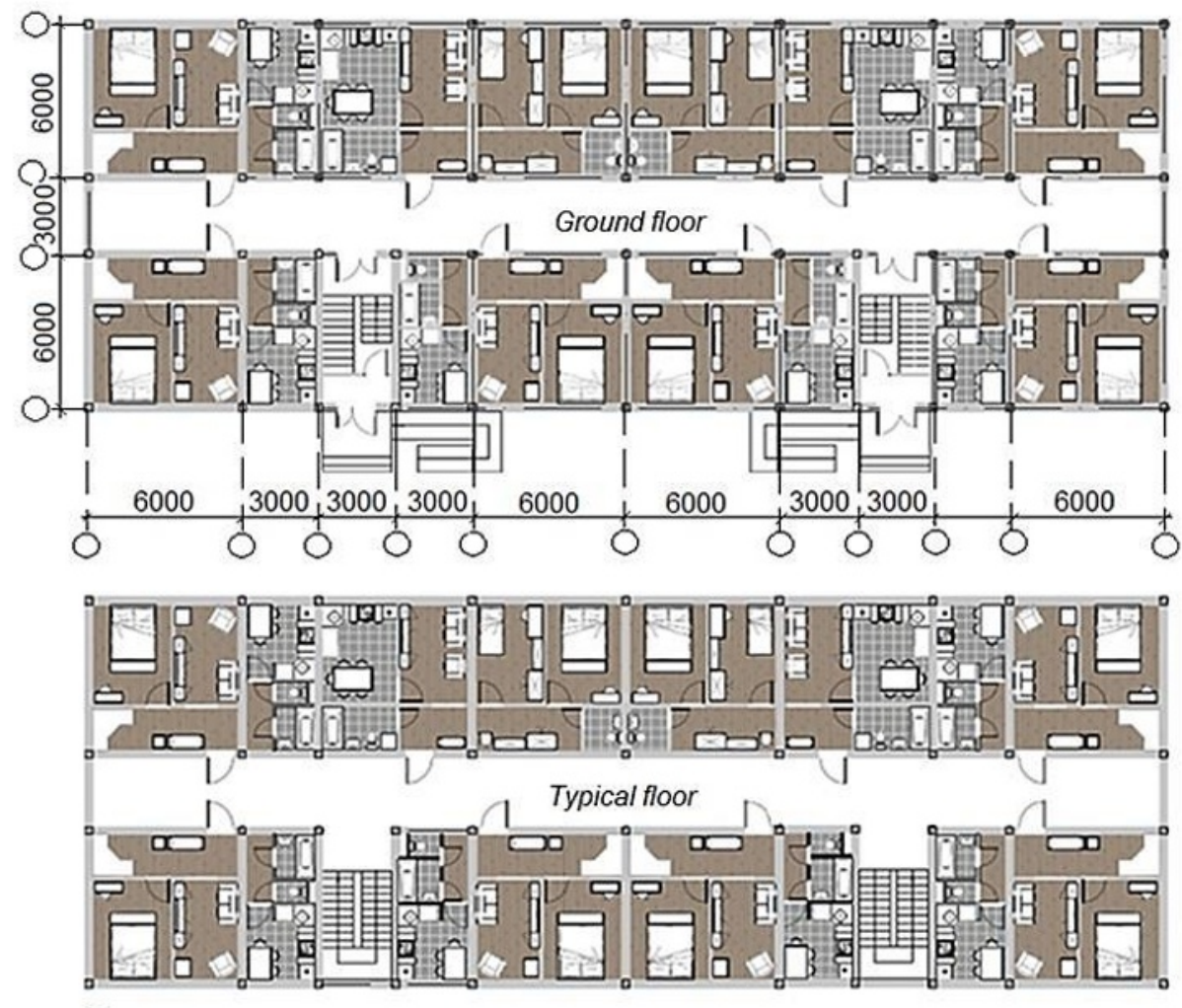

C

Fig. 5. Variants of planning solutions for residential buildings: blocked (a), gallery (b), corridor (c) types

The development of typical planning modules for residential buildings on the basis of structural space-planning cells of steel frames not only does not exclude, but also stimulates the individualization of the design solution. Such open typing with the possibility of interchangeable structural elements provides ample opportunities for a large number of combinatorial combinations of unified products and allows us to eliminate the uniformity of space-planning solutions of buildings while streamlining and reducing the total number of standard sizes of building products.

The unification of space-planning parameters and structural elements of steel frames will create a system of typical design, in which the object of typification is not the house, but typical unified structures from which buildings are formed, varying in space-planning structure and architecture, which will ensure the flexibility and maneuverability of the building production for the mass construction of residential low-rise buildings. Production capacities of Russian manufacturers of metal structures today make it possible to introduce this design method into the practice of mass construction of civil buildings, including low and medium-rise residential buildings, and to solve the problem of affordable and highquality housing in Russia.

\section{References}

1. E. Glaeser, Triumph of the City: How Our Greatest Invention Makes Us Richer, Smarter, Greener, Healthier, and Happier, p 352 (2011) 
2. The volume of housing construction in Russia in 2014 exceeded the Soviet record figures [Online] URL http://www.minstroyrf.ru/press/obemy-stroitelstva-zhilya-vrossii-v-2014-g-prevysili-sovetskie-rekordnye-pokazateli/

3. The floors of the current construction in April 2018 remained at the same level (graphics) [Online] URL https://erzrf.ru/news/etazhnost-tekushchego-stroitelstva-vaprele-2018-goda-ostalas-na-prezhnem-urovne-

grafiki?costFrom $=0.7 \& \operatorname{costTo}=8.7 \& \operatorname{tag}=\% \mathrm{D} 0 \% \mathrm{AD} \% \mathrm{D} 1 \% 82 \% \mathrm{D} 0 \% \mathrm{~B} 0 \% \mathrm{D} 0 \% \mathrm{~B} 6 \% \mathrm{D} 0$ $\%$ BD\%D0\%BE\%D1\%81\%D1\%82\%D1\%8C

4. Passport of the priority project "Forming a comfortable urban environment" [Online] URL http://www.minstroyrf.ru/upload/iblock/337/pasport-prior.-proekta-i-gorsreda.pdf

5. A.Y. Virva, Perception of architectural objects by city dwellers: subjective-semantic analysis, p 287 (2017)

6. Eko-Viikki. Eco-Viikki - Aims and implementation and results. Ministry of the environment. Cidade de Helsínquia. Vaatan. ISBN: 952-473-455-9. 2005. [Online] URL: https://http://www.hel.fi/static/ksv/julkaisut/eco-viikki_en.

7. S.M. Anpilov, Russia Fundamentals of Economics, Management and Law 2(2) pp 29$36(2012)$

8. Y. Geyl, Cities for people p276 (2012)

9. The dream of a house: where Russians want to live [Online] URL: https://www.rbc.ru/politics/11/08/2017/598c9a989a794752bcf2eb6c

10. V.M. Tusnina, J. Industrial and civil construction 6 pp 43-46 (2015)

11. Average construction cost per square meter of total living space [Online] URL: http://gks.ru/free_doc/new_site/business/stroit/sr_stoim.xls

12. Tariffs for maintenance and repair of residential premises in Moscow [Online] URL: http://youhouse.ru/tarify_zhkh/moskva\%20remont\%20pomewenija.php

13. V. Nelson, Wind Energy: Renewable Energy and the Environment, Second Edition $\mathrm{p}$ 338 (2013)

14. E.L. Belyaeva, The architectural and spatial environment of the city as an object of visual perception (Moscow: Stroiizdat ) p 127 (1977)

15. T.A. Kornilov, G.N. Gerasimov, J. Industrial and civil construction 3 pp 41-45 (Russia, 2015)

16. A.R. Tusnin, J. Industrial and civil construction 11 pp 18-22 (Russia, 2017)

17. O.A. Tusnina, J. Industrial and civil construction 11 pp 23-27 (Russia, 2017)

18. O.A. Tusnina, J. Magazine of Civil Engineering 5(73) pp 25-39 (Russia, 2017)

19. V.M. Tusnina, D.Sh. Fayzov, J. Industrial and civil construction 4 pp 19-24 (Russia, 2017)

20. A.R. Tusnin, A.A. Kolyago, J. Modern science and innovation 3(15) pp 141-148 (Russia, 2016)

21. A.R. Tusnin, P.A. Varaksin, J. Industrial and civil construction 10 pp 10-13 (Russia, 2018)

22. SP 55.13330.2016 Single-family houses (Moscow: Minstroy of Russia)

23. SP 31-107-2004 Architectural and planning solutions for multi-residential buildings (Moscow: Gosstroy of Russia) 